\title{
Agenda forestieră europeană și internațională în timpul Preșe- dinției României la Consiliul Uniunii Europene
}

\author{
I. Popa, I.N. Ivășchescu
}

Popa I., Ivășchescu I.N., 2019. European and international forestry agenda during the Presidency of Romania at the Council of the European Union. Bucov. For. 19(2): 169-172.

Abstract. The European and international forestry agenda during the Romanian Presidency of the Council of the European Union included three major themes: the European Forest Strategy, the United Nations Forum on Forests - UNFF14 and the Forest Europe process with reference to the negotiations on the Legally Binding Agreement on Forests in Europe. Council conclusions on the European Commission communication on the Progress in the implementation of the EU Forest Strategy appreciates the progress made in the implementation of the European forestry strategy, pointing out some directions where action needs to be accelerated both at European and national level. For the period 2019-2020, additional efforts are needed to making full use of financial instruments provided by EU, to strengthen the initiatives of the Member States that promote the integration of nature conservation in the sustainable management of forests and enhancing communication and awareness of the value and importance of forests and their sustainable management. A new forest strategic framework must continue to support the sharing of best practices and to enhance the communication on the importance of forests to the implementation of Agenda 2030 for sustainable development, corroborated with an adequate funding.

The second item on the international forestry agenda during the Romanian Presidency of the Council of EU was the United Nations Forum on Forests - UNFF14. The technical debates in the forum highlighted the essential role of forests in addressing the urgent global challenges of climate change, underlining the urgent need for further action. Different actions on climate change related to forests, such as reducing deforestation and forest degradation, promoting sustainable forest management techniques aimed at maximizing carbon storage, promoting afforestation and reforestation initiatives, must be tailored to the local specificity.

The EU and its Member States support the resuming and finalizing negotiations on a legally binding agreement on forests in Europe as soon as possible in the context of its transfer within UNECE with the support of FAO.

Keywords: forest policy: Council of European Union, UNFF, Forest Strategy

Authors. Popa Ionel (popaicas@gmail.com) - "Marin Drăcea” National ResearchDevelopment Institute in Forestry, Station Câmpulung Moldovenesc, 73bis, Calea Bucovinei, 725100 Câmpulung Moldovenesc, Romania; Ivășchescu Iulia Natalia - Ministerul Mediului, Apelor și Pădurilor, Direcția Generală Păduri, Calea Plevnei 46-48, București, România.

Manuscript received December 18, 2019; revised December 24, 2019; accepted December 28, 2019; online first December 31, 2019. 
Consiliul Uniunii Europene este instituția ce reprezintă guvernele statelor membre și, alături de Parlamentul European, are rol legislativ și de coordonare a politicilor uniunii. Funcţionarea Consiliului Uniunii Europene se realizează prin cele 10 formațiuni sau ,configurații", una pentru fiecare din domeniile politicii comunitare, coordonate de reprezentanții țărilor membre, la nivel de demnitari de înalt rang, respectiv miniștri sau secretari de stat. Activităţile tehnice de suport ale Consiliului Uniunii Europene se realizează în grupurile de lucru și comitete specializate, denumite grupuri de pregătire ale Consiliului.

Conform principiului președinției rotative a Consiliului Uniunii Europene, România a deținut între 1 Ianuarie și 30 Iunie 2019 această funcție.

Problemele forestiere se discută, în principal, în grupul de lucru pentru păduri din cadrul Consiliului pentru Agricultură şi Pescuit. Agenda forestieră europeană și internațională pe durata Președinției României a cuprins trei teme majore: Strategia forestieră europeană, Forumului Națiunilor Unite pentru Păduri UNFF14 şi procesul Forest Europe, cu referire la negocierile privind Acordul juridic cu caracter obligatoriu pentru pădurile Europei.

În data de 7 Decembrie 2018 Comisia Europeană a publicat „Comunicarea privind progresele realizate în implementarea strategiei forestiere europene", document tehnic de evaluare a nivelului de îndeplinire a obiectivelor strategice asumate pe domeniul forestier, în perioada 2014-2018 (COM(2018) 811). Raportul a evidențiat progresele semnificative în atingerea obiectivelor stabilite pentru 2020, în cele opt domenii prioritare ale strategiei. De la adoptarea sa, strategia forestieră europeană a facilitat coordonarea tuturor politicilor naționale relevante pentru păduri și sectorul forestier. S-a reușit, astfel, o abordare consecventă, atât în politicile interne cât și pe plan internaţional, întrucât UE și statele membre au susținut gestionarea durabile a pădurilor.

România, în calitate de deținătoare a Președinției Consiliului Uniunii Europene, a 170 propus și a obținut acordul politic al statelor membre pentru elaborarea unui set de concluzii politice privind progresele înregistrate în punerea în aplicare a Strategiei Forestiere Europene, precum și un nou cadru strategic pentru păduri. La nivelul grupului de lucru pentru păduri s-au elaborat şi negociat o serie de concluzii politice, ce au stat la baza unui document agreat în ședința Consiliului de Agricultură și Pescuit, din 15 Aprilie 2019. La acel eveniment s-au recunoscut progresele realizate în implementarea Strategiei Forestiere Europene, evidențiind direcțiile în care este necesară o accelerare a acțiunilor, atât la nivel comunitar, cât și național. Consiliului Uniunii Europene, prin concluziile politice adoptate, consideră necesară intensificarea eforturilor comune, în următoarele direcții:

(i) Politica forestieră, conform tratatelor UE, este de competența țărilor membre și toate deciziile și politicile referitoare la păduri trebuie să respecte principiul subsidiarității și competența statelor membre.

(ii) Strategia forestieră europeană reprezintă un cadru de referință ce facilitează coordonarea unor politici coerente atât la nivel comunitar cât și al statelor membre, cu impact asupra pădurilor şi sectorului forestier, evidențiind necesitatea intensificării schimbului de bune practici în gestionarea sustenabilă a pădurilor.

(iii) Pentru perioada 2019-2020 este necesară suplimentarea fondurilor, în vederea operaționalizării instrumentelor financiare și a măsurilor de dezvoltare rurală în domeniul forestier, precum și consolidarea inițiativelor statelor membre (ex. rețeaua europeană INTEGRATE) ce promovează integrarea conservării naturii în managementul durabil al pădurilor, concomitent cu îmbunătăţirea comunicării și sensibilizării societății cu privire la importanța gestionării durabile a pădurilor.

La nivelul grupului de lucru pentru păduri, România a negociat și promovat poziția politică privind o nouă strategie forestieră europeană după 2020, principal suport al consolidării politicilor forestiere intracomunitare. Această nouă strategie trebuie să sprijine continuarea 
schimbului de bune practici și îmbunătățirea comunicării, având în vedere importanța tot mai mare a pădurilor în atingerea obiectivelor strategice la nivel global, concretizate în Agenda 2030 pentru dezvoltare durabilă. Noile direcții strategice trebuie însoțite de o finanțare adecvată și o reducere semnificativă a procedurilor administrative, având drept principii directoare recunoașterea rolului multifuncțional al pădurilor şi promovarea gestionării durabile a acestora, în concordanță cu rezoluțiile şi deciziile ministeriale ale Forest Europe.

Consiliul Uniunii Europene solicită Comisiei Europene demararea de urgență a procedurile de elaborare a unei noi strategii în domeniul forestier. Concluziile Consiliului UE privind stadiul implementării strategiei forestiere europene și noi direcții strategice post 2020 au fost prezentate public, de către România în numele Consiliului UE, la conferința Pădurile Noastre, Viitorul Nostru - Gestionarea Durabilă a Pădurilor privind Abordarea Provocărilor Societății, organizată de Comisia Europeană în 25-26 aprilie 2019 la Bruxelles.

Dezbaterile politice privind o nouă strategie forestieră europeană au continuat și pe durata președinției Finlandei la consiliul UE, atât la nivelul grupului de lucru pentru păduri cât și în plenara Consiliului de Agricultură și Pescuit. În prezent acest obiectiv privind domeniul forestier se află pe agenda noii Comisii Europene estimându-se publicarea noi strategii forestiere europene în cursul anului 2020.

Cel de-al doilea subiect major aflat pe agenda forestieră internaţională din timpul Președinției României la Consiliul UE a fost reprezentat de Forumul Naţiunilor Unite pentru Păduri - UNFF14 din perioada 5-8 mai 2019 de la sediul ONU, New York. Uniunea Europeană, prin intermediul grupului de lucru pentru păduri, a elaborat și a susţinut în plen poziții tehnice şi politice referitoare la principalele teme de discuție din cadrul forumului. Dezbaterile tehnice din cadrul forumului și concluziile desprinse au vizat următoarele aspecte de interes comun la nivel internațional:

(i) S-a subliniat rolul esențial al pădurilor în fața provocărilor globale urgente de combatere a schimbărilor climatice subliniindu-se necesitatea stringentă de acțiuni suplimentare. Forumul și Parteneriatul de colaborare pentru păduri trebuie să acorde o atenție deosebită asigurării coerenței, coordonării și colaborării politicilor internaționale privind pădurile și clima, concomitent cu mobilizarea unui nivel adecvat de resurse financiare pentru implementarea acțiunilor necesare.

(ii) Diferitele acțiuni privind schimbările climatice legate de păduri, cum sunt reducerea defrişărilor și a degradării pădurilor, promovarea tehnicilor durabile de gestionare a pădurilor orientate spre maximizarea stocării carbonului, promovarea inițiativelor de împădurire şi reîmpădurire, trebuie adaptate specificului local.

(iii) Contribuția potențială a pădurilor la creșterea economică inclusivă și durabilă trebuie recunoscută în mod explicit în politicile internaționale și naționale. Dezvoltarea și implementarea cu succes a politicilor forestiere depinde în mod esenţial de implicarea, expertiza şi antreprenoriatul comunităților locale. Securitatea drepturilor de proprietate și de utilizare a resurselor forestiere reprezintă o condiție necesară pentru gestionarea durabilă a pădurilor. Pentru a se asigura o creștere economică durabilă în sectorul forestier este necesară asigurarea accesului echitabil pe piață și a sprijinului financiar pentru comunităţile locale.

Problematica unui acord juridic cu caracter obligatoriu pentru păduri la nivel european a reprezentat un punct important al agendei forestiere europene, mai ales prin relansarea procesului de negociere, întrerupt în 2013, și transferul acestuia în cadrul UNECE cu sprijinul FAO. Discuțiile din grupul de lucru pentru păduri din cadrul Consiliului UE au evidenţiat poziția comună a statelor membre și sprijinul, condiţionat, pentru reluarea și finalizarea într-un timp cât mai scurt a negocierilor referitoare la acest acord juridic-cadrul pentru păduri, cu relevanță la nivel european extins.

România, prin Ministerului Apelor și 
Pădurilor și echipa de experți implicată pe durata Președinției Consiliului UE, a dovedit că are capacitatea tehnică și politică de a propune şi de a negocia, cu succes, politica forestieră la nivel european și internațional.

Agenda forestieră europeană și internațională în anul 2020 este dominată de discuțiile privind elaborarea unei noi strategii forestiere europene adaptată și circumscrisă noului Pact Ecologic European, de negocierile referitoare la acordul juridic pentru pădurii, cu caracter obligatoriu, precum și al XV-lea Forum al Naţiunilor Unite pentru Păduri de la New York din luna mai 2020.

Participarea activă a României în procesele de decizie cu impact asupra pădurilor, la nivelul Uniunii Europene și la nivel internaţional, prin implicarea echipelor de experți în diferitele grupuri de lucru și comitete tehnice de la nivelul Consiliului Uniunii Europene, Comisiei Europene, ONU, FAO, UNECE sau Forest Europe, coroborate cu poziţii politice clare și consecvente, reprezintă premisa integrării reale a sectorului forestier în contextul european și internațional. Promovarea specificului național în ceea ce privește gestionarea durabilă a pădurilor la masa dialogului și deciziei trebuie să reprezintă o prioritate majoră a autorităţii naţionale pentru silvicultură.

\section{Mulțumiri}

Autorii doresc să aducă mulțumiri întregirii echipe tehnice a Ministerului Apelor și Pădurilor şi Reprezentanței permanente a României la Uniunea Europeană, în special doamnelor Corina Aldea, Lăcrămioara Chioaru, Florentina Petcu, Diana Gorun și Larissa Buru, pentru sprijinul acordat pe durata asigurării Președinției Grupului de Lucru pentru Păduri din cadrul Consiliului Uniunii Europene. Aprecierile noastre se îndreaptă și către revizorii lucrări pentru sprijinul acordat în îmbunătăţirea prezentului material. 